\title{
TECHNIQUES OF LAND DEVELOPMENT IN NEW ZEALAND
}

By P. W. SMALLFIELD, Director, Extension Division, Department of Agriculture, Wellington.

Land development in New Zealand is essentially a matter of pasture establishment, and for the work to be economic. pastures of the perennial ryegrass-white clover type have generally been essential. These demand fairly exacting seed-bed and soil fertility conditions for establishment and sustained, production, and the practices that have been adopted to secure suitable conditions will form the major part of my discussion of land development.

\section{Virgin Land}

Land development naturally started on the more fertile soils and where preparation of a suitable seedbed was technically easy; hence the rapid development of surface-sown pastures on bush burns where the initial seed-bed was ideal for the establishment of a nerennial ryegrass-white clover type of pasture. That such pastures were not likely to last. long (and this was foreseen by a few discerning people) did not deter land developers, for the initial years of high production generally gave a satisfactory return on establishment costs.

Bush land would not have been developed if the initial pastures had provided only the carrying capacity of the present swards of danthonia and browntop.

After the exhaustion of unimproved areas of fertile ploughable or bush land attention was given to scrub areas where the natural fertility was low and where the preparation of a suitable seed-bed was often costly. St is on these areas and on deteriorated surfacesown hill country that land development has progressed during the last 30 years.

The four factors important in marginal land development are: fertiliser treatment to correct soil fertility deficiencies, the use of perennial strains of ryegrass and white clover, the preparation of suitable seed-beds to secure establishment, and controlled graz- 
ing. These are four rather obvious prerequisites for the successful establishment of a perennial ryegrasswhite clover pasture, but they were not as obvious 40 years ago as they are today. Then the obvious plants for low fertility land were low fertility demanding grasses, and often quite carefully conducted smallscale plot work confirmed this view. The conception of the potential of perennial ryegrass-white clover swards on scrub and heath lands had to await the initiation of work on a sufficiently large scale to co-ordinate adequate livestock management with the type of pasture established, for perennial ryegrass-white clover swards respond to capacity stocking.

\section{Fertilisers}

The use of phosphatic fertilisers initiated early progress on scrub land development. The practice of topdressing started in the Waikato in the early 1880's on the Horotiu sandy loam soils and enabled a grassclover sward to be maintained on these light and not naturally fertile soils. The initiation of phosphatic topdressing as a farm practice on one soil type provided the guide for the treatment of other soil types and led slowly to the investigation of the fertiliser requirements of an ever-widening range of soils.

First soils which responded well to phosphates alone were developed.; then areas which required lime and phosphates, or lime, phosphates, and potash ; and latterly areas where minor element deficiencies hindered progress have responded to treatment. Cobalt, Molybdenum, and copper (where appropriate) have been quickly incorporated in land development practice.

The use of nitrogen has never been economic in marginal land development, although nitrogen has been the outstanding soil deficiency. Suitable fertiliser treatment secured clover establishment and growth and thus opened the way for marginal land development, but success was not fully realised until truly perennial strains of ryegrass were available. Before reliance could be placed on ryegrass the final swards on marginal land were usually browntop and white clover, or cocksfoot, Yorkshire fog, and white clover, which were not sufficiently productive to recover the cost of development and maintenance.

\section{Seeds Mixture}

Perennial ryegrass and white (and/or subterranean) clover form the basis of grass mixtures used for the development of cultivatable land. For the first three decades of the present century the bulk of com- 
mercial lines of perennial ryegrass were of the false perennial type and provided only short-lived plants. With these strains the development of marginal land or even the renewal of pastures on land of good quality was a hazardous undertaking.

Certified strains of perennial ryegrass and white clover came on the market at the beginning of the 1930's and their availability ushered in an era of land development which has made a very important contribution to the expansion of our livestock farming industries.

Why, it may be asked, should perennial ryegrass be so essential in our grasslands and land development procedure?

The answer, I think, lies in the spread of its seasonal production and its ability to thrive under heavy stocking. In total annual production other grasses may outyield it if stocked to suit the plants' requirements, but the management that perennial ryegrass wants is just about what it gets under all-the-yearround commercial grazing practice. Although the perennial ryegrass-white clover pasture may not be ideal for butterfat and meat production, it does produce and thrive under our farm management system.

For high production under our management system perennial ryegrass must be associated with either white or subterranean clover and where summer soil moisture falls so low that white clover may die, subterranean clover is used alone or in association with white. Cocksfoot is generally included with perennial ryegrass and white clover in permanent mixtures, while Paspalum dilatatum, crested dogstail, Lotus uliginosus ( $L$. major), and cowgrass and Montgomery red clover are valuable in mixtures for particular soils and climatic conditions. With autumn-sown pastures short-rotation or Italian ryegrass is generally included in the mixture for early feed.

Seed-bed

Success in grassing virgin land depends very largely on securing a satisfactory strike of grasses and clovers and strike is greatly influenced by the condition of the seed-bed and the weather. The seed-bed should be firm, fine, moist, and warm at the time of sowing and of these conditions firmness is possibly the most important. If the seed-bed is not firm, clovers do not strike, and without clovers the grasses do not flourish and many plants die, leaving bare land which in the second year becomes covered in clovers striking from 
later germinating seeds. The pasture may then go through a very clovery phase for several years, with consequent loss in production and difficulty in management.

A properly firmed seed-bed gives an even strike of grasses and clovers and with satisfactory aftermanagement a well-balanced pasture of grass and clover. The necessity for firmness conditions cultivation procedures, which follow no set pattern, but which aim to bring the seed bed to the desired state for sowing when the weather is likely to be' favourable.

Where the land is flat or undulating the seed-bed is usually prepared after ploughing and consolidated by rolling and/or fallowing, but where the land is too step for rolling surface working with discs and harrows is resorted to. Even light surface cultivation given by concentrating cattle on very steep land may give a satisfactory seed-bed and this practice is sometimes adopted where the natural manuka or other scrub cover is too light to produce sufficient ash cover for sowing after a burn.

Seed-bed preparation by ploughing practically eliminates the reappearance of manuka, but on light surface-worked or ash seed-beds manuka is likely to reinfest pastures where subsequent management is not efficient. For North Island early autumn is the most favourable time for sowing except on areas at an elevation of $1000 \mathrm{ft}$ or more, when late spring sowing is usually favoured; similar procedures are followed in the northern parts of the South Island, but late spring sowing is the general practice.

\section{Marginal Land Development}

Many classes of land are now being developed, the most important of which are the manuka heath lands, the hilly surface-sown grasslands, and the tussock grasslands. A description of the development procedures on the pumice lands, the gumland podzols, and the surface-sown grasslands of the North Island will, I think, suffice to broaden the outlines of the principles of land improvement and pasture establishment which I have already enumerated.

\section{Pumice Land}

- Modern procedures in scrub land development owe much to experience gained from State development of pumice lands, for it was on these soils that a large-scale example was given of as it were plastering a first-class perennial ryegrass-white clover pasture on-, what in appearance and experience was a very third-class soil. 


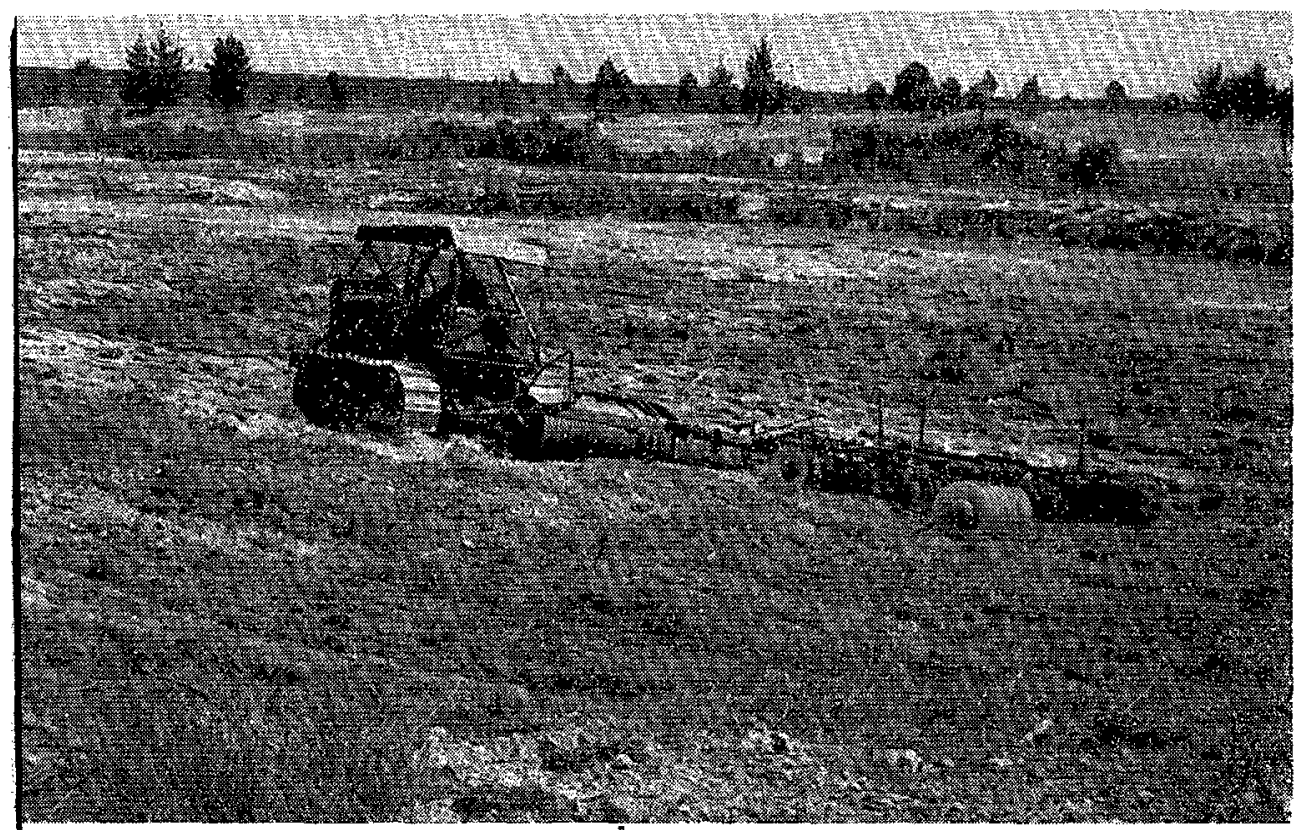

Modern procedures in scrub land development owe much to experience gained from State development of pumice lands. Rolling and discing on a State development block in the Taupo district.

Nearly all the evidence was against its success ; the soil was a light sandy silt covered in tussock, manuka, and manoao scrub; the existing pastures and previous experimental work failed to provide any evidence of success with perennjal ryegrass and indicated that a cocksfoot-Yorkshire fog-white clover pasture might exist for a few years, but that for permanence reliance had better be placed on browntop, chewings fescue, and danthonia.

To develop this land to carry browntop or danthonia pastures was obviously uneconomic and unless first-class pastures could be established and maintained, the land would be best left alone. There was, however, evidence that. on the gumland podzols of North Auckland (which in their natural state look equally unattractive) truly perennial strains of ryegrass would survive. This then could be tried on the pumice lands if the work was done on a sufficient scale to warrant proper grazing management..

Early workers on scrub land development were insistent on the need for gradually raising soil fertility in stages with a perennial ryegrass-white clover pasture as the ultimate goal. They advised develop- 
ment through temporary pastures and the ploughing under of clover and other leguminous crops, an expensive and not very efficacious method. On pumice soils a new procedure was developed based on (1) sowing a nermanent pasture on a well-prepared seed-bed, (2) liberal application of fertiliser, and (3) efficient stocking. These practices allowed the pasture itself to build up surface soil fertility rapidly.

Seed-bed preparation on pumice land is carried out by first burning the dry scrub after it has been rolled and crushed; then the land is ploughed, rolled on the furrow to consolidate the bottom of the seed-bed, worked up with the discs and harrows, and rolled with a Cambridge roller before and after sowing. The pumice lands are at an elevation of 1000 to $2000 \mathrm{ft}$, and spring sowing is usually more successful than autumn sowing. Spring sowing takes place from early October to early December and autumn sowings from late February to early March. Final seed-bed preparation should not dry out the soil too much and the working down of the rolled furrow slices and final seed-bed preparation should just precede sowing.

The general seeds mixture consists of perennial ryegrass 20 to $25 \mathrm{lb}$, cocksfoot 5 to $8 \mathrm{lb}$, white clover $2 \mathrm{lb}$, and cowgrass (or Montgomery red clover) 2lb. For autumn sowing $51 \mathrm{~b}$ of Italian ryegrass or $51 \mathrm{~b}$ of shortrotation ryegrass may be added. Red clover grows luxuriantly on pumice land, but the danger is that its luxuriant growth may smother out ryegrass and white clover. If red clover is sown, its growth must be controlled by grazing with heavy concentration of cattle and wethers. If stocking is adequate, the. tramping and manuring from large numbers of stock rapidly improve the pasture sward, but if grazing is inadequate and a smother occurs, the results are disastrous.

The seeds mixture is usually sown with $3 \mathrm{cwt}$ of superphosphate, and another $3 \mathrm{cwt}$ is applied from 4 to 6 months after sowing and another 3cwt 12 months after sowing; thereafter the land should be dressed with 2 to $3 \mathrm{cwt}$ of superphosphate a year. These applications are designed to enable grass and clover plants to cover all bare ground quickly. Soon after the grasses and clovers strike, their growth is limited-with spring sowings by dry summer weather and autumn sowings with cold.

Applications of nitrogenous fertilisers soon after sowing have not proved very efficacious or economic, but superphosphate applied to a spring sowing in the early autumn or to an autumn sowing in the early 
spring encourages white clover quickly to fill up bare ground. The application of three dressings of 3cwt of super-phosphate within the first 12 months has proved quite effective in securing a close sward of perennial ryegrass and white clover. The pumice soils -do not respond to lime, and potassic fertilisers have proved necessary only after 10 or more years of dairying. Cobalt, of course, must be applied and is given as cobaltised superphosphate for annual topdressing.

\section{Gumland Podzols}

Manuka heath land, occurring on podzols of varying degrees of maturity, forms another class of marginal land on which development is very active at present. The soils are heavier than the pumice soils and a lengthy fallow is necessary to allow weathering to assist fining and firming of the seed-beds.

Before tractors came into general use the heavier soil types were usually twice ploughed-first in the autumn to allow the furrow slices to weather in the winter and the land was then reploughed and worked down in the late spring and summer fallowed before autumn sowing. Now most seed-bed preparation is done with the giant discs ; a preliminary cut is given in the autumn to allow winter weathering without loss of soil by erosion and then further giant discing is done in the spring to work up a summer fallow which is finally brought to a seed-bed by light discs and harrows for autumn sowing.

Seeds mixture and fertiliser practice are generally similar to that for pumice land, except that paspalum and Lotus uliginosus are usually included in seeds mixtures for northern areas and lime is required. The usual application is 1 ton of lime per acre, but some of the soils respond to molybdenum and on these $10 \mathrm{cwt}$ of lime and $2 \frac{1}{0} \mathrm{oz}$ of sodium molybdate often now replace 2 tons of lime.

\section{Surface Sown Country}

Improvement of hill country surface-sown pastures of danthonia and browntop is now being actively undertaken. both by resowing after surface cultivation with discs or by oversowing of clovers and topdressing. Cultivation work is confined to the easier country, and practices are somewhat similar to those described for manuka heath land on gumland podzols, although on surface-sown hill country it is fairly common practice to take a fodder crop first and then resow to grass.

The first heavy discing is usually done in the 
autumn or early winter and this cultivation moves only part of the surface soil ; it allows the moved soil to weather, but not to erode, which is most important on steep country. Further cultivation is given in the spring to prepare a seed-bed for a summer sown root crop or green forage crop or for autumn-sown grass. If a fodder crop is taken, the land is lightly cultivated in the spring and sown to grass or cultivated over the summer and sown in the autumn. Pasture mixtures and fertiliser treatment are generally similar to those described for gumland podzols.

- Where land is too steep for cultivation pasture improvement is carried out by oversowing clovers and topdressing. The usual procedure is to oversow $21 \mathrm{~b}$ of white clover and llb of subterranean clover along with 2 to $3 \mathrm{cwt}$ of superphosphate per acre from aeroplanes. Successful strikes are most common where the existing pastures are well eaten down and the oversown seed gains contact with the soil.

As fertiliser applications are not very effective without clovers and clovers do not thrive without fertilisers, the success of the oversowing depends essentially on, clover strike. Much has yet to be learned about seed-bed preparation for oversowing, as it is not yet generally possible to prepare a seed-bed for the introduction of grasses without cultivation, and this is impossible on very steep country. In general, however, oversowing is quite successful and has been the means of improving. very large areas of surface-sown hill c o u n try;

Livestock and Pastures

Controlled grazing plays an important part in successful pasture establishment and our farmers have long used livestock for this purpose. In the early days of bush and bracken fern burns controlled grazing was necessary to prevent reversion and on most pastoral country a definite sheep : cattle ratio is required for efficient pasture control.' For developing marginal scrub land grazing management is particularly important, because heavy controlled grazing at appropriate times is essential for building soil fertility. Take, for example, pasture establishment on pumice lands where a pasture sown in the spring or autumn provides very little grazing until the following spring, when (if initial establishment has been-, successful and adequate fertilisers have been. applied) it comes away with great vigour. This vigorous growth must be fully controlled with cattle and sheep if sustained growth is to be maintained over the late spring, summer, and autumn 
and a sward built up to provide 'a useful permanent pasture. Rotational grazing is to be preferred for this first summer grazing and beef cattle and wethers are ideal for the purpose. Dairy cows rotationally grazed are equally effective provided the mower is used to trim pastures to keep an even growth and any surplus is cut early for silage rather than cut later for hay.

Spring and summer set stocking of new pastures with ewes and lambs does not give as useful control as is given with cattle and dry sheep rotationally grazed. Controlled grazing over the first spring and summer of a newly sown pasture on marginal land is essential for the development of the productive perennial ryegrass-white clover pasture and it is unwise to judge the value of development work until new pastures are 18 months or 2 years old. A well-established pasture can be ruined by unsatisfactory stocking during the first summer, while a partial failure can often be nursed to success with judicious grazing.

\section{Perennial Ryegrass-white clover Pastures}

Where rainfall and soil moisture conditions are adequate land development in New Zealand aims at establishing and maintaining a perennial ryegrasswhite clover type of pasture and development is successful where soil fertility deficiencies are known and can be corrected. I have endeavoured to enumerate our practices in this work and these in telling seem so simple as to be commonplace. The real lesson which I think we can learn is that the whole job from initial cultivation to grazing must be done thoroughly. It is better not to start the work at all than to skimp any phase of it.

Q. Why in establishing grass do you use cattle instead of sheep and ewes?

A. It depends a good deal on circumstances. The areas that I was considering in relation to sheep and cattle were the pumice soils of central North Island where heavy tramping of cattle is essential for the consolidation of the pastures. You may have areas in Westland where your grazing management is possibly as difficult as anywhere owing to the higher rainfall. The essential point reallv is that you want to get your first grazings all done before your land is too wet. In the North Island it is essential with the grazing of cattle, to get pastures sown as early as possible in the autumn so that the first grazing can be done before the land becomes wet in winter. Grazing must be conditioned by the soil moisture. It is essential in pasture establishment on poor land to use livestock to turn the grass growth into manure and to consolidate the pasture; but in the first year do not over graze. Livestock grazing should be looked on as a pasture-establishing rather than a profit-making enterprise during the first year. 